Tersedia online di: http://ejournal-balitbang.kkp.go.id/index.php/ma

\title{
KEBERHASILAN MASKULINISASI DAN KINERJA REPRODUKSI IKAN GAPI, Poecilia reticulata DIBERI EKSTRAK SERBUK SARI PINUS MELALUI PAKAN
}

\author{
Eka Kusuma, Agus Oman Sudrajat", Harton Arfah, dan Alimuddin \\ Departemen Budidaya Perairan, Fakultas Perikanan dan IImu Kelautan, Institut Pertanian Bogor \\ J.. Agatis, Dramaga Bogor 16680
}

(Naskah diterima: 2 Agustus 2021; Revisi final: 11 November 2021; Disetujui publikasi: 11 November 2021)

\begin{abstract}
ABSTRAK
Tujuan penelitian ini adalah untuk mengevaluasi efektivitas suplementasi ekstrak serbuk sari pinus melalui pakan terhadap maskulinisasi dan kinerja reproduksi ikan gapi. Penelitian ini menggunakan rancangan acak lengkap (RAL) yang terdiri atas lima perlakuan dengan tiga ulangan, yaitu meliputi suplementasi 10 mg ekstrak serbuk sari pinus per kg pakan (SSP10), $50 \mathrm{mg} \mathrm{kg}^{-1}$ pakan (SSP50), $250 \mathrm{mg} \mathrm{kg}^{-1}$ pakan (SSP250), $1 \mathrm{mg} 17 \alpha$-metiltestosteron per kg pakan sebagai kontrol positif (MT atau kontrol-2), dan perlakuan tanpa suplementasi ekstrak serbuk sari pinus (kontrol-1). Ikan uji yang digunakan adalah induk gapi bunting diberi pakan perlakuan selama 15 hari dan dipelihara sampai anak kelahiran pertama (B1) dan kedua (B2). Hasil penelitian menunjukkan bahwa pemberian ekstrak serbuk sari pinus mampu meningkatkan persentase nisbah kelamin jantan pada B1, namun tidak pada B2. Suplementasi ekstrak serbuk sari pinus pada induk bunting tidak memengaruhi kinerja reproduksi. Persentase nisbah kelamin jantan B1 pada perlakuan SSP50 dan SSP250 tidak berbeda nyata, secara berurutan 63,9\%dan 66,4\% tetapi keduanya lebih tinggi dibandingkan kontrol-1 (31,3\%); namun masih lebih rendah dibandingkan perlakuan MT $(81,9 \%)(P<0,05)$. Perlakuan MT pada B2 memiliki nisbah kelamin jantan tertinggi $(48,4 \%$ dan berbeda nyata dengan perlakuan lainnya $(P<0,05)$. Suplementasi ekstrak serbuk sari pinus melalui pakan efektif dalam meningkatkan persentasi nisbah kelamin jantan ikan gapi pada dosis $50 \mathrm{mg} \mathrm{kg}^{-1}$. Ekstrak serbuk sari pinus dapat digunakan untuk maskulinisasi ikan gapi.
\end{abstract}

KATA KUNCI: maskulinisasi; serbuk sari pinus; Poecilia reticulata; kinerja reproduksi; $17 \alpha$ metiltestosteron

ABSTRACT: Effectiveness of pine pollen extract-supplemented feed on masculinization and reproductive performance of the guppy, Poecilia reticulata. By: Eka Kusuma, Agus Oman Sudrajat, Harton Arfah, and Alimuddin

The aim of this study was to evaluate the effectiveness of pine pollen extract supplementation through feed on masculinization and reproductive performance of guppy. This study used a completely randomized design consisting of five treatments with three replications. The treatments were the supplementation of pine pollen extract of $10 \mathrm{mg} \mathrm{kg}^{-1}$ of feed (SSP10), $50 \mathrm{mg} \mathrm{kg}^{-1}$ of feed (SSP50), and $250 \mathrm{mg} \mathrm{kg}^{-1}$ of feed (SSP250). Control treatments consisted of the supplementation of $1 \mathrm{mg} 17 \alpha$-methyltestosterone per $\mathrm{kg}$ of feed as a positive control (MT or control-2), and without supplementation pine pollen extract in feed (control-1). The test fish used were livebearer guppy brooders. The test fish were given treatment feed for 15 days and continued until the first (B1) and second (B2) offsprings were born. This study showed that the administration of pine pollen extract in feed was able to increase the percentage of male sex ratio in B1, but not in B2. Supplementation of pine pollen extract did not affect the tested fish's reproductive performance. The percentages of male sex ratio B1 in the SSP50 and SSP250 treatments were not significantly different, $63.9 \%$ and $66.4 \%$ respectively. Despite that, both treatments had a higher male sex ratio than control-1 $(31.3 \%$, yet lower than the MT treatment $(81.9 \%)(P<0.05)$. The MT treatment at B2 had the highest male sex ratio $(48.4 \%$ and was significantly different from the other treatments $(P<0.05)$. Supplementation of pine pollen extract through feed at a dose of $50 \mathrm{mg} \mathrm{kg}^{-1}$ effectively increased the male sex ratio of guppy. Pine pollen extract can be used for the masculinization of guppy.

KEYWORDS: masculinization; pine pollen; Poecilia reticulata; reproduction performance; $17 \alpha$ methyltestosterone

\footnotetext{
* Korespondensi: Departemen Budidaya Perairan, Fakultas Perikanan dan IImu Kelautan, Institut Pertanian Bogor. Jl. Agatis, Dramaga Bogor 16680, Indonesia E-mail: agusom@ apps.ipb.ac.id
} 


\section{PENDAHULUAN}

Ikan gapi termasuk dalam lima jenis ikan hias paling diminati di Indonesia. Kementerian Kelautan dan Perikanan mencatat pada tahun 2015 produksi ikan gapi nasional mencapai 26.613 ekor dan meningkat menjadi 72.229 ekor pada tahun 2016 (KKP, 2019). Pada umumnya ikan gapi yang diminati adalah ikan jantan karena memiliki warna dan motif yang lebih indah dibandingkan gapi betina. Induk gapi mampu melahirkan anak beberapa kali dalam satu kali proses perkawinan, namun budidaya gapi memiliki kendala, yaitu persentase anak jantan lebih rendah dibandingkan betina sehingga dibutuhkan upaya untuk meningkatkan persentase jantan dalam setiap kelahiran, misalnya dengan perlakuan hormonal untuk maskulinisasi.

Hormon yang sering digunakan untuk maskulinisasi adalah hormon sintetik misalnya $17 \alpha-$ metiltestosteron (Chakraborty et al., 2012). Efektivitas hormon $17 \alpha$-metiltestosteron (MT) untuk maskulinisasi sudah terbukti pada berbagai jenis ikan budidaya, namun menemui berbagai kendala di antaranya harus impor, harganya mahal, dan sudah dilarang di Indonesia (No.1/Kepmen-KP/2019). Pelarangan tersebut terkait dengan potensi residu yang dapat memberikan dampak negatif terhadap keamanan pangan dan lingkungan (Rivero-Wendt et al., 2020), serta akumulasi pada sedimen (Homklin et al., 2011) dan kolom air sampai 28 hari (Barry et al., 2011).

Tumbuhan mengandung hormon steroid yang bersifat estrogenik ataupun androgenik, namun belum banyak dipelajari bioaktivitasnya (Tarkowská, 2019). Bahan alami yang mengandung steroid khususnya fitoandrogen di antaranya adalah serbuk sari pinus (Pinus sp.), yang dilaporkan mengandung testosteron, androstenedione, dan epitestosteron (Šaden-Krehula et al., 1971). Penggunaan serbuk sari pinus untuk maskulinisasi telah dilakukan pada ikan nila (Nian et al., 2017) dan lele (Adenigba et al., 2017). Penelitian ini bertujuan untuk menguji efektivitas pemberian ekstrak serbuk sari pinus untuk maskulinisasi dan kinerja reproduksi pada ikan gapi.

\section{BAHAN DAN METODE}

\section{Pembuatan Ekstrak Serbuk Sari Pinus dan Pengukuran Kadar Hormon}

Pembuatan ekstrak serbuk sari pinus (ESSP) menggunakan metode maserasi mengikuti Puspitasari $\&$ Proyogo (2017). Bahan yang digunakan adalah serbuk sari pinus komersial murni $100 \%$ yang diproduksi oleh Kunming Yundao Biotechnology. Kadar hormon testosteron dan estradiol-17 $\beta$ diukur menggunakan metode enzyme-linked immunosorbent assay (ELISA) sesuai petunjuk produsen.

\section{Rancangan Penelitian dan Persiapan Pakan Uji}

Penelitian ini terdiri atas lima perlakuan dan tiga ulangan dengan masing-masing ulangan terdiri atas satu ekor ikan gapi bunting. Perlakuan yang diberikan yaitu tanpa suplementasi ekstrak serbuk sari pinus (kontrol-1), suplementasi dengan dosis 10 (SSP10), 50 (SSP50), dan $250 \mathrm{mg} \mathrm{kg}^{-1}$ pakan (SSP 250), serta suplementasi $17 \alpha$-methyltestosterone $1 \mathrm{mg} \mathrm{kg}^{-1}$ pakan sebagai kontrol-2 (MT). Pakan yang digunakan berupa pelet komersial dengan kandungan protein $40 \%$ Suplementasi ekstrak serbuk sari pinus pada pakan mengikuti metode Adenigba et al. (2017).

\section{Pemeliharaan Ikan}

Ikan uji yang digunakan adalah ikan gapi jenis platinum red tail dengan bobot $0,8-1,0 \mathrm{~g}$. Sebelum diberi perlakuan, induk betina bunting dipelihara secara terpisah dengan jantan selama dua bulan untuk mengosongkan embrio yang dikandungnya dan penyeragaman kondisi ikan uji. Ikan dipelihara dalam akuarium ukuran $30 \mathrm{~cm} \times 20 \mathrm{~cm} \times 20 \mathrm{~cm}$ diisi air sebanyak $9 \mathrm{~L}$ yang diberi keranjang dengan diameter lubang $0,5 \mathrm{~cm}$ agar anak yang dilahirkan terpisah dengan induknya. Pemberian pakan perlakuan dilakukan tiga kali sehari secara at satiation selama 15 hari. Pengukuran pH dan suhu air dilakukan setiap hari, oksigen terlarut (DO) seminggu sekali, dan total ammonia nitrogen (TAN) pada awal dan akhir penelitian. Kualitas air selama penelitian yaitu suhu $28,2^{\circ} \mathrm{C}-28,5^{\circ} \mathrm{C}$; pH 6,9-7,5; DO 4,2-4,3 $\mathrm{mg} \mathrm{L}^{-1}$; dan TAN 0,25-0,43 $\mathrm{mg} \mathrm{L}^{-1}$.

\section{Analisis Kadar Hormon Testosteron dan Estradiol-17 $\beta$}

Sampel yang digunakan untuk mengukur kadar hormon adalah plasma tubuh. Kadar hormon pada induk bunting dilakukan pada awal dan pasca pemberian perlakuan, plasma tubuh diambil dari tiga ekor ikan per perlakuan. Pengukuran kadar hormon juga dilakukan pada anak gapi kelahiran pertama dari induk gapi bunting yang diberi perlakuan. Pengukuran dilakukan pada hari ke-0, 10, 20, 30, dan 40 hari pascalahir. Jumlah ikan yang digunakan sebanyak lima ekor tiap ulangan. Sampel ikan (wholebody) digerus sampai hancur dalam tabung mikro, kemudian ditambahkan phosphate-buffered saline (pH 7,4) dengan perbandingan 1:4. Sampel disentrifus $5.000 \mathrm{rpm}$ pada suhu $4^{\circ} \mathrm{C}$ selama 10 menit, kemudian cairan bening dipindahkan ke mikro tube yang baru dan disimpan pada suhu $-20^{\circ} \mathrm{C}$ hingga dilakukan pengukuran. Pengukuran kadar hormon dilakukan menggunakan metode ELISA dengan kit testosteron (DRG Diagnostic EIA 1559) dan hormon estradiol-17 $\beta$ (kit estradiol-17 $\beta$ DRG EIA 2693) sesuai petunjuk produsen. 
Pengukuran kadar hormon dihitung menggunakan program MPM 6.

\section{Parameter Pengamatan}

Parameter yang diamati untuk menguji efek penambahan ekstrak serbuk sari pinus dalam pakan terhadap maskulinisasi dan kinerja reproduksi ikan gapi adalah:

Nisbah kelamin jantan anak kelahiran pertama (B1) dan kedua (B2) pada 60 hari pasca lahir (hpl) diamati berdasarkan fisiologi ikan yaitu warna dan adanya gonopodium pada ikan jantan, dihitung berdasarkan rumus:

Nisbah kelamin jantan $=\frac{\text { Jumlah ikan jantan }}{\text { Jumlah total ikan }} \times 100$

Jumlah anak pada B1 dan kedua B2

Sintasan B1 dan B2 $60 \mathrm{hpl}=\frac{\text { Jumlah anak ikan akhir }}{\text { Jumlah anak ikan awal }} \times 100$

Gonadosomatik index (GSI) B1 jantan dan betina Pada 60 hari pasca lahir

$$
\mathrm{GSI}=\frac{\text { Bobot gonad }}{\text { Bobot tota I ikan }} \times 100
$$

Hepatosomatic index (HSI) betina Pada 60 hari pasca lahir

$$
\mathrm{HSI}=\frac{\text { Bobot hati }}{\text { Bobot total ikan }} \times 100 \%
$$

Histologi testis B1 $60 \mathrm{hpl}$ diidentifikasi berdasarkan Uribe et al. (2014) dan ovarium B1 diidentifikasi berdasarkan Uribe et al. (2019).

Jarak kelahiran dari B1 ke B2

\section{Analisis Data}

Data diolah dengan bantuan Microsoft Excel 2016. Analisis nisbah kelamin jantan dan kinerja reproduksi dilakukan dengan analisis varian (ANOVA) menggunakan SPSS versi 18, jika ditemukan perbedaan nyata kemudian dilakukan uji lanjut dengan menggunakan uji Duncan pada derajat kepercayaan $95 \%$

\section{HASIL DAN BAHASAN}

Kadar hormon testosteron dan estradiol-17 $\beta$ dalam ESSP disajikan pada Tabel 1. Hasil pengujian kadar hormon menunjukkan bahwa proses ekstraksi serbuk sari pinus dapat meningkatkan kadar hormonnya. Serbuk sari pinus tanpa ekstrak mengandung testosteron 9,9 $\mathrm{ng} \mathrm{mg}^{-1}$ dan estradiol-17 $\beta$ tidak terdeteksi. Setelah dilakukan ekstraksi menggunakan alkohol 96\%diperoleh kandungan hormon testosteron mencapai 64,6 $\mathrm{ng} \mathrm{mg}^{-1}$ dan estradiol-17 $\beta 2,2 \mathrm{ng} \mathrm{mg}^{-1}$.
Nisbah kelamin jantan (NKJ) pada perlakuan SSP50 dan SSP250 adalah tidak berbeda nyata (63,9\% dan $66,4 \%$, namun berbeda nyata dengan perlakuan kontrol-1 tanpa pemberian ESSP yaitu 31,3\%( $(P<0,05)$. Nisbah kelamin jantan tertinggi dihasilkan pada perlakuan kontrol-2 (MT), yaitu 81,9\% (Tabel 2). Pemberian ESSP pada induk gapi bunting terbukti mampu meningkatkan NKJ pada anak gapi kelahiran pertama. Maskulinisasi terjadi karena antara induk dengan embrio dihubungkan oleh pembuluh darah sebagai saluran metabolisme yang membentuk folikel plasenta (Uribe et al., 2019) sehingga testosteron pada induk dapat ditransfer kepada embrio. Terjadinya maskulinisasi pada anakan yang dihasilkan dari induk yang diberi pakan mengandung ekstrak SSP karena pada saat masih menjadi embrio berumur 14 hari sebelum lahir primodial germ cells (PGC) sudah terbentuk dan pada awal kelahiran sudah berkembang menjadi gonad (Koya et al., 2003).

Maskulinisasi yang terjadi pada suplementasi ESSP melalui pakan induk gapi bunting lebih rendah dibandingkan dengan suplementasi $17 \alpha$ metiltestosteron dikarenakan dalam ESSP mengandung estradiol-17 $\beta$ yang bekerja berlawanan dari testosteron sehingga proses maskulinisasi tidak maksimal. Hormon sintetis $17 \alpha$-metiltestosteron lebih maksimal dalam memaskulinisasi ikan karena murni dan sulit terdegradasi (Homklin et al., 2011). Hormon $17 \alpha$-metiltestosteron dalam pakan menunjukkan hasil yang stabil beberapa bulan karena ditambahkan gugus metil pada rantai karbon ke-17. Waktu paruh dari $17 \alpha$-metiltestosteron sekitar 1,1 bulan pada suhu $40^{\circ} \mathrm{C}$ dan 4,8 bulan pada suhu $22^{\circ} \mathrm{C}$ (Barry et al., 2007). Bakteri mempunyai kemampuan lebih untuk mendegradasi testosteron yang tidak memiliki gugus metil (Fahrbach et al., 2010).

Nilai GSI jantan dan betina pada B1 dan B2 (Tabel 2 ) seluruh perlakuan tidak berbeda nyata $(P>0,05)$. Nilai GSI B1 jantan berkisar antara 2,9-3,4 sedangkan GSI betina berkisar antara 2,8-3,5. Nilai HSI betina berkisar antara 2,2-3,7; dan tidak berbeda nyata untuk semua perlakuan $(P>0,05)$.

Nisbah kelamin jantan pada B2 hanya perlakuan MT yang masih terjadi maskulinisasi $(48,4 \%$ atau $12 \%$ lebih tinggi dibandingkan kontrol, sedangkan pada perlakuan ESSP tidak terjadi maskulinisasi $(P>0,05)$. Terjadinya proses maskulinisasi pada anak kelahiran kedua yang diberi suplementasi $17 \alpha$-metiltestosteron karena diduga masih ada residu yang tersisa di dalam tubuh induk ikan gapi bunting. Residu $17 \alpha$-metiltestosteron mulai tidak terdeteksi setelah dua bulan penelitian (Dergal et al., 2016) dan empat bulan setelah pemberian (Suseno et al., 2020). 
Tabel 1. Kadar testosteron dan estradiol-17 $\beta$ serbuk sari pinus

Table 1. Testosterone and estradiol-17 $\beta$ levels of pine pollen

\begin{tabular}{|c|c|c|}
\hline \multirow{2}{*}{ Bahan (Ingredient ) } & \multicolumn{2}{|c|}{ Kandungan steroid (Steroid content ) (ng mg ${ }^{-1}$ ) } \\
\hline & Testosteron (Testosterone) & Estradiol-17 $\beta$ (Estradiol-17 $\beta$ ) \\
\hline Ekstrak bunga pinus lokal (Pinus merkusii ) & $>67.2^{* *}$ & $4.9 \pm 0.1$ \\
\hline Serbuk sari pinus komersial (Commercial pine pollen ) & $9.9 \pm 0.1$ & Tidak ter deteksi (Not detected) \\
\hline $\begin{array}{l}\text { Ekstrak serbuk sari pinus komersial* } \\
\text { Commercial pine pollen extract* }\end{array}$ & $64.6 \pm 2.6$ & $2.2 \pm 0.1$ \\
\hline \multicolumn{3}{|c|}{$\begin{array}{ll}\text { Keterangan (Note): } \\
* \quad \text { Bahan yang digunakan penelitian (Used in this study) } \\
\text { ** } \quad \text { Kandungan lebih tinggi dari standar alat untuk membaca kadar hormon (The hormone level was higher than the } \\
\text { standard tool for reading the hormone level) }\end{array}$} \\
\hline
\end{tabular}

Tabel 2. Nisbah kelamin jantan anak gapi kelahiran pertama (B1) dan kedua (B2) dari induk bunting yang diberi perlakuan ekstrak serbuk sari pinus

Table 2. Sex ratio of the first (B1) and second-born (B2) offspring from female pregnant guppy fed with pine pollen extract supplemented feed

\begin{tabular}{|c|c|c|c|c|c|}
\hline \multirow{3}{*}{$\begin{array}{l}\text { Perlakuan } \\
\text { Treatments }\end{array}$} & \multirow{3}{*}{ NKJ $(\%)$} & \multirow{2}{*}{\multicolumn{2}{|c|}{$\frac{\text { B1 }}{\text { Betina (Female) }}$}} & \multirow{2}{*}{\multicolumn{2}{|c|}{$\frac{\text { B2 }}{\text { Jantan (Male) }}$}} \\
\hline & & & & & \\
\hline & & GSI & HSI & HSI & NKJ $(\%)$ \\
\hline Kontrol-1 (Control-1) & $31.3 \pm 2.9^{a}$ & $2.88 \pm 0.1^{a}$ & $2.23 \pm 0.1^{\mathrm{a}}$ & $3.05 \pm 0.3^{a}$ & $36.4 \pm 2.9^{\mathrm{a}}$ \\
\hline MT & $81.9 \pm 3.6^{d}$ & $3.56 \pm 0.4^{\mathrm{a}}$ & $3.1 \pm 0.9^{\mathrm{a}}$ & $2.96 \pm 0.2^{\mathrm{a}}$ & $48.4 \pm 4.9^{b}$ \\
\hline SSP10 & $54.4 \pm 7.3^{b}$ & $2.96 \pm 0.3^{\mathrm{a}}$ & $3.19 \pm 0.1^{\mathrm{a}}$ & $3.46 \pm 0.5^{a}$ & $34.7 \pm 7.5^{\mathrm{a}}$ \\
\hline SSP50 & $63.9 \pm 1.2^{c}$ & $3.02 \pm 0.2^{a}$ & $2.93 \pm 0.8^{\mathrm{a}}$ & $3.24 \pm 0.3^{a}$ & $35.0 \pm 0.1^{\mathrm{a}}$ \\
\hline SSP250 & $66.4 \pm 4.5^{c}$ & $3.37 \pm 0.5^{\mathrm{a}}$ & $3.75 \pm 1.2^{\mathrm{a}}$ & $3.20 \pm 0.0^{a}$ & $34.7 \pm 4.5^{\mathrm{a}}$ \\
\hline
\end{tabular}

Keterangan: Huruf berbeda di tiap kolom (nilai rata-rata \pm SD) menunjukkan berbeda nyata (uji jarak berganda Duncan; $P<0,05$ )

Note: $\quad$ Different letters in the same column (mean \pm SD) indicate a significant difference (Duncan's multiple distance test; $P<0.05$ )

Kadar hormon testosteron dan estradiol-17 $\beta$ pada induk betina disajikan pada Gambar 1. Sebelum perlakuan diberikan, kadar testosteron dan estradiol$17 \beta$ pada induk gapi bunting masing-masing adalah $0,5 \mathrm{ng} \mathrm{mL}^{-1}$ dan $1,7 \mathrm{ng} \mathrm{mL}^{-1}$. Pasca-perlakuan (H-16), kadar testosteron pada induk betina meningkat dibandingkan hari ke-0, dan kadar tertinggi diperoleh pada perlakuan $\mathrm{MT}\left(7,8 \mathrm{ng} \mathrm{mL}^{-1}\right)$, diikuti oleh perlakuan SSP250 (5,2 $\left.\mathrm{ng} \mathrm{mL}^{-1}\right), \operatorname{SSP} 50\left(5,0 \mathrm{ng} \mathrm{mL}^{-1}\right)$, SSP10 (3,6

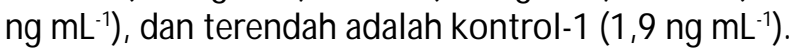
Sebaliknya kadar estradiol-17 $\beta$ tertinggi diperoleh pada perlakuan kontrol-1 $\left(6,5 \mathrm{ng} \mathrm{mL}^{-1}\right)$, sedangkan perlakuan lainnya berkisar $0,0-0,3 \mathrm{ng} \mathrm{mL}^{-1}$. Testosteron dalam plasma tubuh induk gapi bunting setelah diberikan perlakuan ESPP mengalami peningkatan karena testosteron dalam ESSP diserap melalui pencernaan dan masuk ke dalam darah. Berbagai bahan dari serbuk sari terbukti mampu meningkatkan kadar testosteron misalnya pemberian serbuk sari kurma (date palm pollen) dapat meningkatkan testosteron dalam serum pada tikus prapubertas dan dewasa (Mehraban et al., 2014).

Kadar hormon testosteron dan estradiol-17 $\beta$ anak gapi kelahiran pertama disajikan pada Gambar 2. Hormon testosteron B1 berumur $0 \mathrm{hpl}$ tertinggi diperoleh pada perlakuan MT 7,0 $\mathrm{ng} \mathrm{mg}^{-1}$; sedangkan estradiol-17 $\beta$ pada anak umur $0 \mathrm{hpl}$ tertinggi diperoleh pada perlakuan kontrol-1 3,6 $\mathrm{ng} \mathrm{mg}^{-1}$.

Pemberian ESSP melalui pakan selama 15 hari pada induk gapi bunting mampu menginduksi testosteron pada anak kelahiran pertama sampai hari ke-30 lebih tinggi dibandingkan estradiol-17 $\beta$, sedangkan hari ke40 relatif stabil. Kadar hormon testosteron akan meningkat sesuai dengan bertambahnya umur ikan dan akan mencapai puncaknya ketika ikan matang gonad (Nakamura, 2013).

Kinerja reproduksi berdasarkan parameter jumlah anak, sintasan, dan jarak kelahiran antara B1 dan B2 


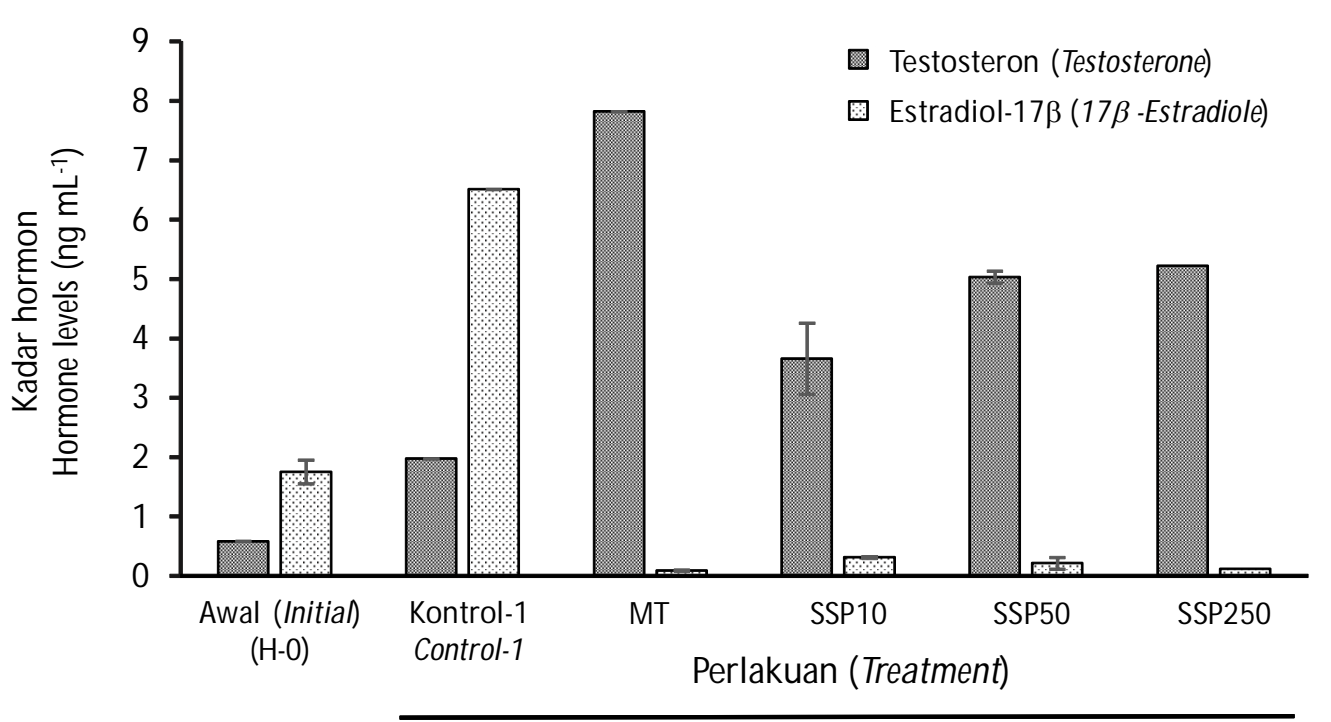

Pasca perlakuan (Post treatments)

Gambar 1. Kadar hormon testosteron dan estradiol-17 $\beta$ induk gapi betina bunting awal $(\mathrm{H}-0)$ dan pasca perlakuan ( $\mathrm{H}-16)$.

Figure 1. Testosterone and estradiol-17 $\beta$ levels at initial $(\mathrm{H}-0)$ and post-treatment $(\mathrm{H}$ 16) of female pregnant guppy.

disajikan pada Tabel 3. Jumlah anak B1 adalah tidak berbeda nyata untuk semua perlakuan yaitu 17-25 ekor/ induk dan B2 (23-25 ekor/induk). Jumlah anak tersebut relatif kecil jika dibandingkan dengan hasil penelitian Shahjahan et al. (2014) yang melaporkan induk gapi mampu menghasilkan anak 40-89 ekor tiap gram bobot induk.

Sintasan B1 tidak berbeda nyata yaitu $84,1 \% 92,5 \%$ dan B2 83,8\%90,0\%(P>0,05). Pemberian serbuk sari pinus dalam proses maskulinisasi ikan lele (Clarias gariepinus) juga dilaporkan tidak berpengaruh nyata terhadap nilai sintasan (Adenigba et al., 2017). Jarak kelahiran B1 dan B2 yaitu 23-25 hari juga tidak berbeda pada semua perlakuan $(P>0,05)$. Shahjahan et al. (2014) menyatakan bahwa masa kehamilan atau gestasi ikan gapi berkisar antara 25-35 hari.

Histologi testis dan ovarium B1 dilakukan pada 60 hpl (Gambar 4) menunjukkan bahwa testis semua perlakuan sudah matang ditandai dengan adanya spermatozoa. Ovarium B1 di semua perlakuan menunjukkan sudah matang (tipe 4) namun demikian, telur ikan gapi tidak matang bersamaan. Kematangan telur bervariasi yaitu tipe-1 ditandai dengan inti yang besar hampir menempati seluruh sitoplasma, tipe-2 menunjukkan peningkatan volume sitoplasma dan penurunan volume nukleus (germinal vesicle), sedangkan tipe-3

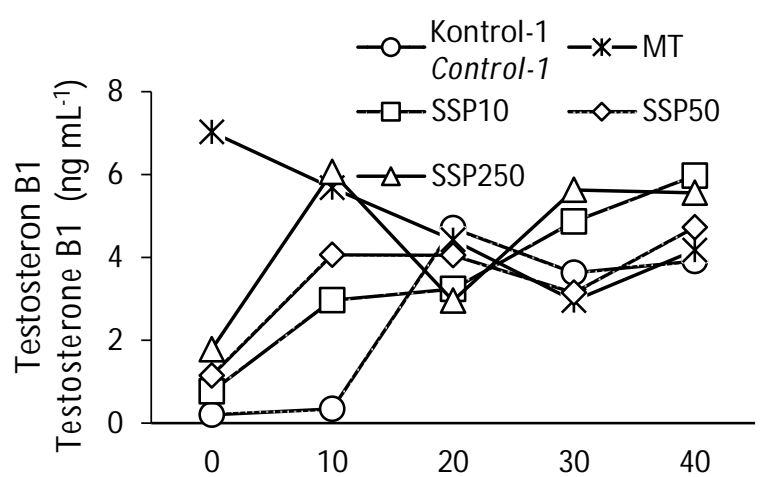

Pengamatan (hari) / Observation (days)

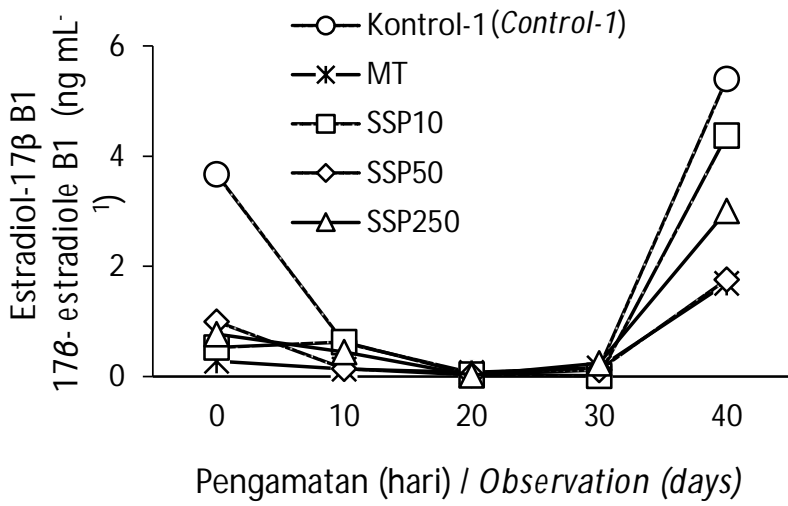

Gambar 2. Kadar hormon testosteron (kiri) dan estradiol-17 $\beta$ (kanan) pada anak gapi kelahiran pertama (B1).

Figure 2. Testosterone (left) and estradiol-17 $\beta$ (right) levels in the first-born guppy fry (B1). 
Tabel 3. Jumlah anak, sintasan, dan jarak kelahiran anak pertama dan kedua dari induk ikan gapi bunting yang diberi perlakuan ekstrak serbuk sari pinus

Table 3. Number of offspring, survival rate, and birth distance of the first to second-born from female of pregnant guppy treated with pine pollen extract-supplemented feed

\begin{tabular}{|c|c|c|c|c|c|}
\hline \multirow[b]{2}{*}{$\begin{array}{l}\text { Perlakuan } \\
\text { Treatments }\end{array}$} & \multicolumn{2}{|r|}{ B1 } & \multicolumn{2}{|r|}{ B2 } & \multirow[b]{2}{*}{$\begin{array}{c}\text { Jarak kelahiran } \\
\text { B1-B2 (hari) } \\
\text { Birth distance } \\
\text { B1-B2 (day) }\end{array}$} \\
\hline & $\begin{array}{c}\text { Jumlah anak } \\
\text { (ekor) } \\
\text { Number of } \\
\text { fish (tail) }\end{array}$ & $\begin{array}{c}\text { Sintasan } 60 \mathrm{hpl} \\
\text { Survival rate } 60 \mathrm{hpl} \\
(\%)\end{array}$ & $\begin{array}{c}\text { Jumlah anak } \\
\text { (ekor) } \\
\text { Number of } \\
\text { fish (tail) }\end{array}$ & $\begin{array}{c}\text { Sintasan } 60 \mathrm{hpl} \\
\text { Survival rate } 60 \mathrm{hpl} \\
\text { \% }\end{array}$ & \\
\hline Kontrol-1 (Control-1) & $23 \pm 5^{a}$ & $86.1 \pm 3.7^{\mathrm{a}}$ & $24 \pm 1^{\mathrm{a}}$ & $86.2 \pm 6.5^{\mathrm{a}}$ & $24 \pm 1^{a}$ \\
\hline MT & $17 \pm 6^{\mathrm{a}}$ & $84.1 \pm 8.9^{a}$ & $24 \pm 2^{a}$ & $83.8 \pm 11.7^{\mathrm{a}}$ & $24 \pm 2^{\mathrm{a}}$ \\
\hline SSP10 & $21 \pm 12^{\mathrm{a}}$ & $87.9 \pm 3.1^{\mathrm{a}}$ & $25 \pm 1^{\mathrm{a}}$ & $85.3 \pm 5.8^{\mathrm{a}}$ & $25 \pm 1^{\mathrm{a}}$ \\
\hline SSP50 & $19 \pm 3^{a}$ & $92.5 \pm 2.6^{a}$ & $23 \pm 2^{\mathrm{a}}$ & $88.5 \pm 6.1^{\mathrm{a}}$ & $23 \pm 2^{\mathrm{a}}$ \\
\hline SSP250 & $25 \pm 8^{a}$ & $89.8 \pm 8.8^{a}$ & $24 \pm 1^{\mathrm{a}}$ & $90.0 \pm 6.2^{\mathrm{a}}$ & $24 \pm 1^{\mathrm{a}}$ \\
\hline
\end{tabular}

Keterangan: Huruf berbeda di tiap kolom (nilai rata-rata \pm SD) menunjukkan berbeda nyata ik (uji jarak berganda Duncan; $P<0,05$ )

Note: Different letters in each column (mean \pm SD) indicate a significant difference (Duncan's multiple distance test; $P<0.05)$ )

(vitelogenesis) yaitu vesikula kaya lipid di sekitar sitoplasma dan tipe-4 yaitu matang yang ditandai dengan sitoplasma yang melimpah dan gumpalan lipid yang besar. Shahjahan et al. (2014) menyatakan ikan gapi mulai matang gonad pada umur $56 \mathrm{hpl}$.

Pemberian ekstrak serbuk sari pinus yang dikombinasikan dengan suhu atau aromatase inhibitor diperlukan, serta adanya intensitas penambahan waktu pemberian perlakuan sehingga maskulinisasi pada ikan dapat meningkat.

\section{KESIMPULAN}

Pemberian ekstrak serbuk sari pinus melalui suplementasi pakan pada induk bunting ikan gapi mampu meningkatkan nisbah kelamin jantan pada anak kelahiran pertama. Dosis optimal ekstrak serbuk sari
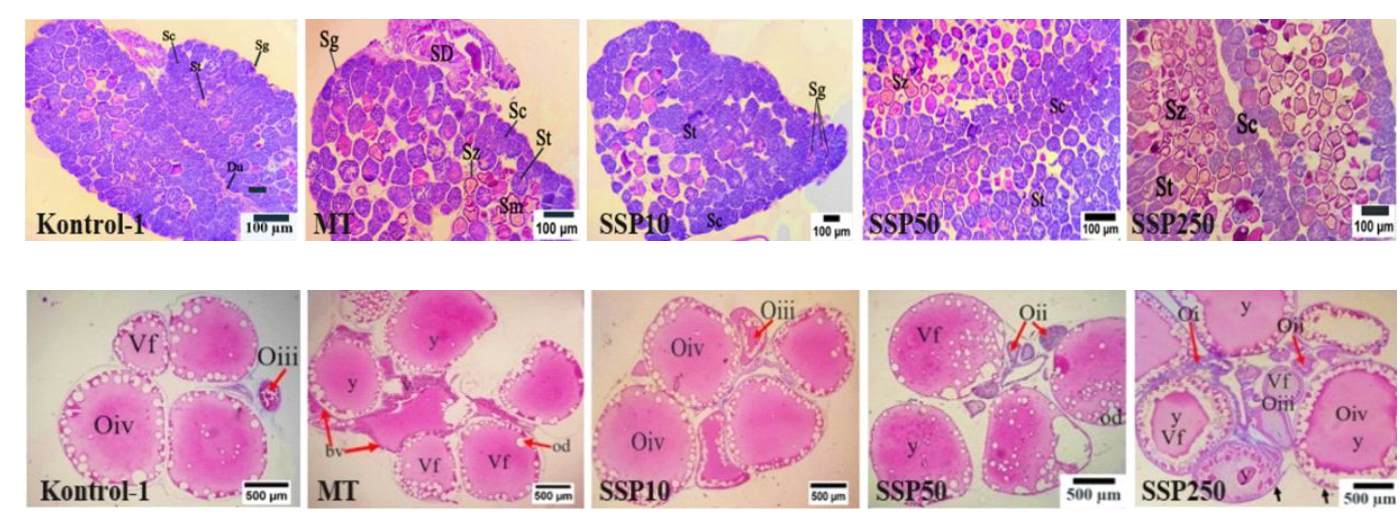

Keterangan: Sel sertoli (S), spermatogonia (Sg), spermatosit (Sc), spermatid (St), spermatozoa (Sz), saluran sperma (SD). Perbesaran 100x. Oosit tipe-1 (Oi), tipe-2 (Oii), tipe-3 (Oiii), tipe-4 (Oiv), previtellogenesis (Pf), inisiasi vitelogenesis (Vf), oil droplet (od), yolk (y), saluran darah (v). Perbesaran 40x

Note: $\quad$ Sertoly cells $(S)$, spermatogonia (Sg), spermatosit (Sc), spermatid (St), spermatozoa (Sz), sperm duct (SD). Magnification 100x. Oocyte type-1 (Oi), type-2 (Oii), type-3 (Oiii), type-4 (Oiv), previtellogenesis (Pf), initiation of vitellogenesis (Vf), oil droplet (od), yolk (y), blood vessel (v). Magnification 40x

Gambar 4. Histologi testis (atas) dan ovarium (bawah) anak gapi kelahiran pertama (B1) pada umur $60 \mathrm{hpl}$.

Figure 4. Histology of testes (top) and ovaries (bottom) of the first-born guppy at 60 days postborn. 
pinus adalah $50 \mathrm{mg} \mathrm{kg}^{-1}$ pakan yang dapat meningkatkan nisbah kelamin jantan sebesar 32,6\% dan tidak berpengaruh negatif terhadap kinerja reproduksi pada induk dan anak ikan gapi kelahiran pertama.

\section{DAFTAR ACUAN}

Adenigba, I., Tumbokon, B.L.M., \& Serrano, A.E. (2017). Androgenic and anabolic effects of pinus tabulaeformis carr. Pollen in Clarias gariepinus. Israeli Journal of Aquaculture - Bamidgeh, 69, 1-8.

Barry, T.P., Marwah, A., \& Marwah, P. (2007). Stability of 17á-methyltestosterone in fish feed. Aquaculture, 271(4), 523-529.

Barry, T.P., Marwah, P., \& Marwah, A. (2011). Transformation of 17 á-methyltestosterone in aquaticsediment systems. Journal of Applied and Natural Science, 3(1), 1-9.

Chakraborty, S.B., Molnár, T., \& Hancz, C. (2012). Effects of methyltestosterone, tamoxifen, genistein and basella alba extract on masculinization of guppy (Poecilia reticulata). Journal of Applied Pharmaceutical Science, 2(12), 48-52.

Dergal, N.B., Scippo, M., Degand, G., Gennotte, V., Mélard, C., Natural, F., Sciences, L., Ahmed, O., \& Bella, B. (2016). Monitoring of 17á-methyltestosterone residues in tilapia's (Oreochromis niloticus) flesh and experimental water after its sex reversal. International Journal of Biosciences, 9(6), 101113.

Fahrbach, M., Krauss, M., Preiss, A., Kohler, H.P.E., \& Hollender, J. (2010). Anaerobic testosterone degradation in Steroidobacter denitrificans: Identification of transformation products. Environmental Pollution, 158(8), 2572-2581.

Homklin, S., Ong, S.K., \& Limpiyakorn, T. (2011). Biotransformation of 17á-methyltestosterone in sediment under different electron acceptor conditions. Chemosphere, 82(10), 1401-1407.

Kementerian Kelautan dan Perikanan [KKP]. (2019). Data produksi nasional perikanan dan kelautan tahun 2018. Diacu 28 Januari 2021. Tersedia pada https://satudata.kkp.go.id/dashboard produksi.

Koya, Y., Fujita, A., Niki, F., Ishihara, E., \& Miyama, H. (2003). Sex differentiation and pubertal development of gonads in the viviparous mosquitofish, Gambusia affinis. Zoological Science, 20(10), 12311242.

Mehraban, F., Jafari, M., Toori, M.A., Sadeghi, H., Joodi, B., Mostafazade, M., \& Sadeghi, H. (2014).
Effects of date palm pollen (Phoenix dactylifera L.) and Astragalus ovinus on sperm parameters and sex hormones in adult male rats. Iranian Journal of Reproductive M edicine, 12(10), 705-712.

Nakamura, M. (2013). Morphological and physiological studies on gonadal sex differentiation in teleost fish. Aqua-BioScience M onograph, 6(1), 1-47.

Nian, C.T., Tumbokon, B.L.M., \& Serrano, A.E. (2017). Pinus tabulaeformis pollen as replacement for 17 alpha-methyltestosterone in the diet of Oreochromis niloticus larvae for sex reversal and growth. Israeli Journal of Aquaculture - Bamidgeh, 69(1), 1-9.

Puspitasari, A.D. \& Proyogo, L.S. (2017). Kadar fenolik total ekstrak etanol daun kersen (Muntingia calabura). Jurnal IImiah Cendekia Eksakta, 2(1), 1-8.

Rivero-Wendt, C.L.G., Miranda-Vilela, A.L., Domingues, I., Oliveira, R., Monteiro, M.S., Moura-Mello, M.A.M., Matias, R., Soares, A.M.V.M., \& Grisolia, C.K. (2020). Steroid androgen 17 alpha methyltestosterone used in fish farming induces biochemical alterations in zebrafish adults. Journal of Environmental Science and Health Part A, 55(11), 1321-1332.

Šaden-Krehula, M., Tajiæ, M., \& Kolbah, D. (1971). Testosterone, epitestosterone and androstenedione in the pollen of scotch pine P. silvestris $L$. Experientia, 27(1), 108-109.

Shahjahan, R.M., Ahmed, M.J., Begum, R.A., \& Rashid, M.A. (2014). Breeding biology of guppy fish, Poecilia reticulata (Peters, 1859) in the laboratory. Journal of the Asiatic Society of Bangladesh, Science, 39(2), 259-267.

Suseno, D., Luqman, E., Lamid, M., Mukti, A., \& Suprayudi, M. (2020). Residual impact of 17-methyltestosterone and histopathological changes in sex-reversed nile tilapia (Oreochromis niloticus). Asian Pacific Journal of Reproduction, 9(1), 37-43.

Tarkowská, D. (2019). Plants are capable of synthesizing animal steroid hormones. M olecules, 24(14), 1-13.

Uribe, M.C., Cruz, G.D.la-R., Alarcón, A.G., Caballero, J.C.C., \& Bárcenas, M.G.G. (2019). Structures associated with oogenesis and embryonic development during intraovarian gestation in viviparous teleosts (Poeciliidae). Fishes, 4(2), 1-14.

Uribe, M.C., Grier, H.J., \& Mejía-roa, V. (2014). Comparative testicular structure and spermatogenesis in bony fishes. Spermatogenesis, 4(3), 1-13. 